Western University

Scholarship@Western

10-1-2019

\title{
Taste and Organization Studies
}

Rita A. Gardiner Ph.D

The University of Western Ontario, rgardin2@uwo.ca

Follow this and additional works at: https://ir.lib.uwo.ca/edupub

Part of the Education Commons, and the Organizational Behavior and Theory Commons

\section{Citation of this paper:}

Gardiner, Rita A. Ph.D, "Taste and Organization Studies" (2019). Education Publications. 175.

https://ir.lib.uwo.ca/edupub/175 


\title{
Taste and organization studies
}

Rita A. Gardiner

The University of Western Ontario

\begin{abstract}
Using the example of the British fish and chip shop, I explore the socio-historical connections among culture, taste and organizations. Specifically, the British "chippie" illustrates how cultural tastes affect our comprehension of organizations. In examining this occupation in depth, we see how the fish and chip shop reveals the ways class and cultural prejudices affect how an organization is perceived. Considering an organization's history offers us a glimpse into how organizational tastes are shaped by broader social processes. Additionally, I explore taste and organizations through diverse theoretical lenses. First, the chippie constitutes an organizational example of Pierre Bourdieu's contrast between taste as luxury and taste as necessity. Second, the work of Hannah Arendt highlights the intersubjective nature of taste, and its connection with judgement. Third, exploring taste with Antoine Hennion's writings reveals the connection between practices and things. Examining taste through diverse theoretical lenses can thus open up productive lines of inquiry for taste and organizational studies.
\end{abstract}

\section{Keywords}

taste, organizations, fish and chip shops, Arendt, Bourdieu, Hennion

\section{Corresponding author:}

Rita A. Gardiner, Faculty of Education, The University of Western Ontario, London, Ontario, Canada N6G 1G7 Email rgardin2@uwo.ca 


\section{Taste and organization studies}

Recently, while scanning The Guardian's website, I came across an image of an early print by David Hockney, depicting three figures in a fish and chip shop. The first figure on the right is Hockney, as a young man, depicted leaning on the counter. The second individual represented is the fish fryer, who is depicted intently focused on his work. Dressed in a white coat, he is also wearing a tie, perhaps to denote respectability. The third figure is of a woman in an apron, captured in the act of wrapping the fish and chips that we may surmise end up as Hockney's supper. The latter two figures represent John Hayden and Janet Smith, owners of Sea Catch, the fish and chip shop in Eccleshill, which Hockney used to visit on his way home from a hard day's graft at Bradford's art school. Like many art students, Hockney was often broke, and used to ask the owners for free food, which they provided to him. In return, Hockey gifted them "Catch of the Day." For many years, his print had pride of place above the fish fryer. When the owners sold up shop in 1970, they took the print home with them, where it was placed about their mantlepiece. For the Smiths, Hockney’s print had a nostalgia value. Today, this print also has a monetary value, as their grandson recently put the print up for auction at Christie's (Baskerville, 2017; Brown, 2017). 
Figure One

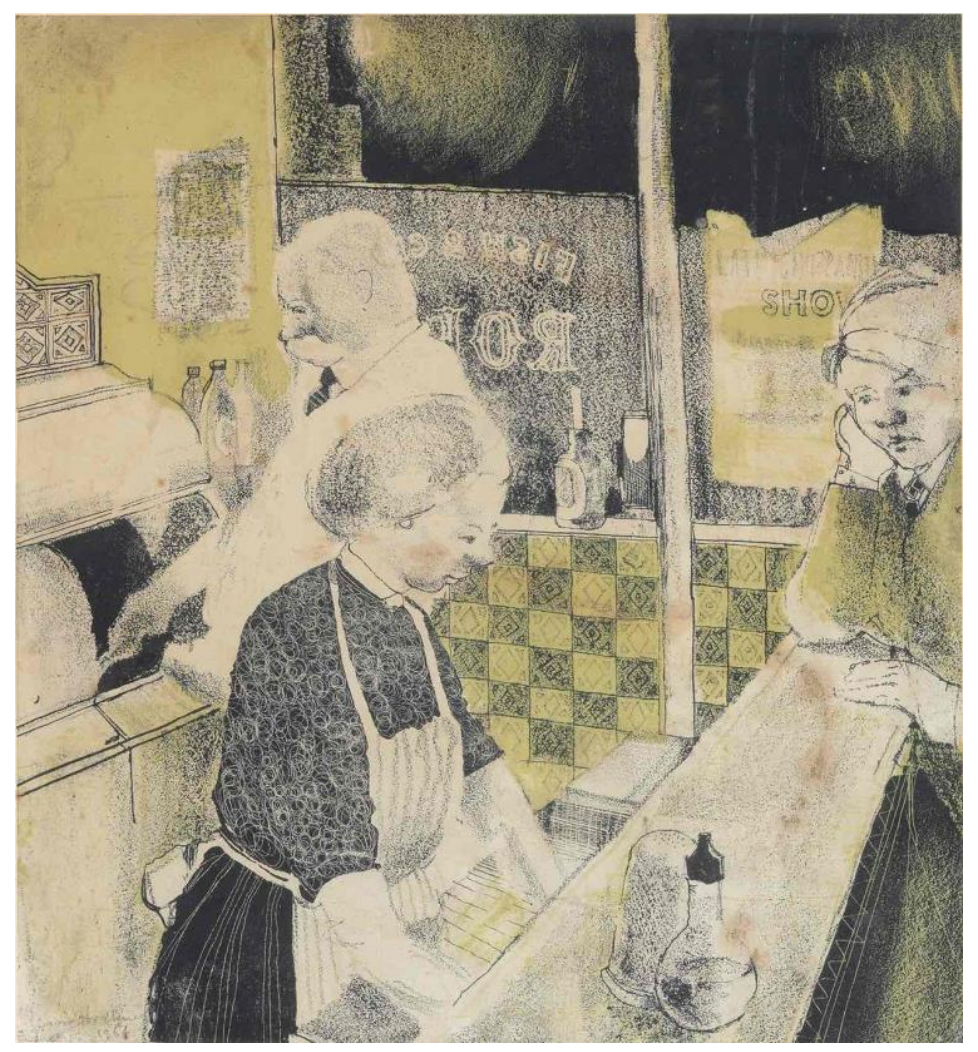

David Hockney’s Fish and Chip Shop (1954) lithograph. Photograph: Christie's

I wonder what customers thought of Hockney's print? Did anyone, while waiting in line for their fish supper, reflect on this image in an aesthetic manner, judging whether or not it was in good taste? After all, one does not usually think about organizational aesthetics in relation to a fish and chip shop. Yet this image offers us a way to consider some of the complexities and contradictions regarding taste and organizations. In this investigation, I take up the call by Cunha, Cabral-Cardosa \& Clegg (2008) to widen the theoretical net of organizational theory, and engage with different perspectives on taste and organizational aesthetics (Strati, 1999; 2007). It is my contention that considering taste through diverse theoretical lenses may reveal new insights on the interconnections between taste and organizations. 
For more than three decades, scholars interested in the concept of taste have often engaged with the work of Pierre Bourdieu. In Distinction, he illustrates how the taste of aesthetics is a bourgeois notion that privileges aesthetic disinterest over the enjoyment of simpler pleasures, such as eating and drinking. Although once at the vanguard of academic debate on taste, Highmore (2016a) contends that Bourdieu's work now constitutes more of a starting point for scholarly discussions. Bourdieu's distinctions on taste have been replaced by competing arguments, such as that of the omnivore/univore distinction (Petersen, 1992; Peterson \& Kern, 1996), as well as organizational scholarship on aesthetics (Strati, 1999, 2010). Yet Bourdieu still has much to offer a study of taste and organizations, especially when coupled with different theoretical viewpoints on taste, such as those of Antoine Hennion and Hannah Arendt.

Arendt is rarely cited in organizational scholarship, even though she regarded taste as a "principle of organization" (Arendt, cited in Brightman, 1995, p. 87). Viewing taste as an organizing principle, as Arendt suggests, shines a light on the collective perception of organizations and those who work within them. But taste is not only an organizing principle; it is also an organizational practice, shaping our collective consciousness about organizational life. As such, thinking with Hennion $(2007 ; 2015)$ alerts us to how taste reveals the active interconnections among people, places and things. His focus on taste as attention also offers insight into the affective, embodied aspects of taste (Hennion 2015; Highmore, 2016a), enhancing our understanding of taste practices. To conclude, I draw together the disparate strands of this conversation to see how attending to taste opens up new research possibilities for the study of organizational life.

To begin, however, I examine the history of the British fish and chip shop to illustrate how cultural ideas about taste influence societal views on organizations. By examining this 
occupation in depth, we see how organizational tastes are not only socially constructed, but also how class and cultural prejudice shapes our perception of specific occupations. Delving into the organizational history of the British fish and chip shop thus offers a vantage point from which to consider some of the ways in which ideas and practices about taste, organizations and culture interweave within the social imaginary.

\section{A distasteful trade?}

There is some dispute as to which is the oldest fish and chip shop in Britain. Some historians contend that Malin's, which opened in 1860 in the East End of London, holds that honour (Panayi, 2014). Many Northerners, however, argue that Lees' Chipped Potato Restaurant in Mossley, Lancashire, which opened in 1863, was the original "chippie," since it sold both fish and chips. What we do know is that, by the 1870s, fish and chips could be purchased in many places across Britain (Walton, 1994).

Until recently, fish and chips was touted as the British national dish. But, in looking into its organizational history, we learn that fish and chips was often regarded as a distasteful business by many middle-class citizens. This bourgeois distaste for the trade began in the nineteenth century, fueled in part by anti-Semitism against the itinerant Jewish fish-sellers who sold their products in London (Panayi, 2014; Walton, 1994). Later, the antipathy toward the industry took on a class-based prejudice, with many middle-class people declaring the dish not only unwholesome, but that eating fish and chips was "uncouth." National pride in this food, therefore, has never been without dissenters.

Prejudice against this business was also apparent in early government legislation. As an instance, in 1907, English government officials introduced the Public Health Act, decreeing the 
fish and chip trade to be an obnoxious industry. The negative effects of this decree were felt strongly across the industry, resulting in many shop owners going out of business. Furthermore, this Act served to perpetuate the social stigma against the trade. This social stigma was further exacerbated when, in the 1920s, fish and chips shops were banned from new suburban developments. In response, the first secretary of the National Federation of Fish Fryers, William Lofts, wrote of "the walls of prejudice" against those employed in the trade (Panayi, 2014).

Paradoxically, however, it was the perceived disreputable nature of this trade that enabled members of the working class, as well as new immigrants to Britain, to set up shop (Panayi, 2014). As a result of the social stigma associated with this occupation, in the early twentieth century, fish shops could be rented cheaply. Moreover, the use of standardized equipment and the simplicity of supplies (fish, potatoes, lard, salt, vinegar) made it relatively easy to establish a business with minimal outlay. Hence, the distasteful manner in which some people viewed the trade proved advantageous to those members of the working class or new immigrants who wanted to gain a foothold in the industry.

Before "setting up shop," many fish fryers had been skilled laborers, and they viewed their new trade as a craft, seeing themselves as more akin to artisans than entrepreneurs (Walton, 1994). As such, they regarded themselves as perpetuating "the best working-class tradition of organization and self-respect," and as the rightful heirs of Victorian radicalism (Walton, 1994, pp. 62-3). Hence many owner-operators not only valued their economic independence, but also valued their place within a working-class community (Walton, 1994).

The first National Fish Fryers Federation (NFFF) broadsheet, published on April 4, 1925, showcases this working-class pride. The purpose of the NFFF's Review was to provide a collective voice for fish fryers so as to foster co-operation and comradeship among its members. 
This comradeship was also demonstrated in fish fryers' early allegiance to socialist values. For example, the majority of members of the (NFFF), which began in 1917, wanted to align their Federation with the Trade Union Congress. As the Federation matured, however, the socialist leanings of its members seemed to wane. Rather than supporting organized labour, fish fryers used their 'solidarity' to try and overcome business restrictions, and obtain greater purchasing power from the fish and potato industries (Panayi, 2014). Another collective aim was to try and get their trade reclassified as a respectable occupation. Yet, this desire for respectability, as well as recognition of the work as skilled labour, was not forthcoming. Thus, the pride that the fish fryers had in their own labour was not one commonly shared by society at large. Rather, the profession was widely regarded as a distasteful occupation (Walton, 1994).

Although perceived as a humble trade by many, fish fryers had the freedom of being their own boss. But this was a hard-earned liberty with long hours and meager recompense. In 1935, for example, the average weekly turnover was $15-20$ pounds, while the net earnings averaged one-two pounds (Walton, 1994). Moreover, the fish and chip shop was not only the family business, it was also the family home. Most families lived at the back or above the shop, often in cramped living quarters. Thus, there was little distinction between organizational and family life since the place of work was also the familiar home. The work in the shop was arduous, and involved long hours (Walton, 1994). Therefore, there was little time for family leisure because the shop dominated family life.

During the 1920s-1960s, fish and chips was a robust enterprise, employing thousands of people, either directly or indirectly. In 1931, for example, across Britain there were an estimated 75,000 people working directly in the fish and chip business (Panayi, 2014). A further 200,000 were employed indirectly in occupations such as transportation, farming and fisheries (Walton, 
1994). For the fishing industry, fish and chip shops represented their largest customer base, with $65 \%$ of white fish being sold to fish fryers. At its peak in 1921, there were 25,000 fish shops across Britain (Panayi, 2014; Walton, 1994).

As the trade matured, the fish and chip industry slowly began to obtain respectability. Co-incidentally, owners started to spend money on decorating their establishments with elaborate tiles, and shiny copper surfaces, thus expressing the trade's self-confidence (Walton, 1994). A further example of this organizational confidence is that fancier eateries opened. As an instance, in 1928, Harry Ramsden opened what was called the first Fish and Chip palace, replete with 200 seats, carpeting and chandeliers (Walton, 1994). But such luxury chippies were unusual, so, too, were chains. Unlike other fast food, fish and chips remained, for the most part, a small family enterprise.

In the 1940s, Mass Observation studies reveal that fish and chips was considered the most popular meal in England (Walton, 1994). In 1971, consumers spent 130 million pounds on fish and chips, more than the combined revenue of other restaurant and fast food businesses. But tastes change and, by the late twentieth century, the heyday of the chippie was coming to an end. By 2003, only 14\% of British families ate a fish supper on a weekly basis (Walton, 1994). Nowadays, global fast food chains occupy the space once dominated by the family-run fish and chip shop.

In considering the history of the fish and chip shop, what emerges is how one organization is shaped by cultural and aesthetic judgements regarding what constitutes "good" and "bad" taste. These judgements have lasting effects on how we perceive organizations. Organizations, and those who work in them, exist in a taste hierarchy that is influenced by sociohistorical concerns about what is deemed tasteful. As Strati (2010) notes "the tastes of working 
people are educated so that they regard one way of working as elegant, another as coarse" (p. 880). Hence, an investigation into an organization's past history offers insight into how cultural prejudice affects not only the aesthetic perception of organizations, but also our ideas about the tastefulness, or lack thereof, of particular occupations.

In pursuing the complex interconnections between taste and organizational life through the socio-historical lens of the British fish and chip shop, we see how cultural prejudices regarding taste demonstrates how cultural norms not only influences individual preferences, but also constructs a particular view of an organization. In what follows, I want to deepen our comprehension of the interconnections between taste, culture and organizations, by considering how specific theorists have approached this topic.

\section{Taste}

Considering taste from diverse perspectives helps us to comprehend some of its effects on organizations. If we consider taste from a phenomenological perspective, for example, one might say that taste is both in the world and within us (Perullo, 2015). From this perspective, taste is "a matter of learning to observe: to observe others but also oneself, because taste concerns everyone" (Perullo, 2015, p. 2). As such, tasting requires not only individual observation, but also necessitates sharing our feelings about taste with others. But sharing our feelings about taste is not always easy, since we do not always comprehend why we prefer some tastes over others (Highmore, 2016b). Taste is not only shaped by individual likes and dislikes, it is also shaped by our socio-cultural milieu. These factors have an influence on the ways we perceive organizations.

The British fish and chip shop offers an organizational illustration of Bourdieu's distinction between the taste of luxury and the taste of necessity as it relates to ongoing class and 
cultural prejudice that affect organizational life. Viewing organizations through a Bourdieusian lens thus illustrates how cultural tastes construct particular perceptions of occupations, and those who work within them. In the West, for example, we have been inculcated to believe that a discerning taste offers greater cultural capital, thus enhancing social status. Yet such discernment, Bourdieu (1984) contends, leads to a "censorship of all bodily manifestations of the act or pleasure of eating" (p. 196). Consequently, he maintains it is wrong to confuse taste with gastronomy, since "taste is the natural gift of recognizing and loving perfection, [whereas] gastronomy is the set of rules that govern the cultivation and education of taste" (p. 68). Societal prejudices in favour of particular taste preferences may thus result in a gastronomical hierarchy, serving to "colour" our taste in food.

Food is an important, albeit often overlooked, component of Bourdieu's argument regarding taste (Lizardo, 2014). Yet Bourdieu maintained there exists a deep structural divide between those middle-class consumers who had a taste for rare or exclusive items, defined as a taste for freedom or luxury, and the more practical tastes of working-class consumers, which he referred to as a taste of necessity. These distinctions are apparent not just in the food we eat, but also in how we consume food. Eating with one's fingers, for example, a common way to eat fish and chips, is sometimes derided for its coarseness. It is thus the manner in which we eat, as well as the foodstuff consumed, that influenced cultural perceptions about taste.

Individual tastes are intricately connected with our socio-cultural environment, as well as our earliest memories that are inscribed onto the body. This embodied connection between culture and self forms what Bourdieu calls our cultural habitus, a key component of his theory of taste (Lizardo, 2014). Habitus represents what Bourdieu describes as a 'structuring structure,' which refers to how we develop certain tastes within particular constraints. Tastes acquired early 
in life offer us a deep-seated feeling of comfort. This past acquisition has a sticky quality, influencing future taste preferences.

Our taste preferences are also linked to our embodied competences, attracting us to some things and repelling us from others. Indeed, it is our distastes that are strongest, according to Bourdieu. What disgusts us is not just an individual preference, but is consolidated from lessons learned at home, at school, and in our local communities. These primary experiences run deep, influencing our inclinations, albeit in a largely unconscious way. Consequently, "when habitus encounters a social world of which it is the product, it is like a fish in water, it does not feel the weight of water, and it takes the world about it for granted" (Bourdieu \& Wacquant, 1992, p. 242). Yet although our tastes are conditioned by these early encounters, our tastes can change as we adapt to different life circumstances (van Eijck, 2001). Thus, tastes are both formative and malleable.

\section{Taste and subjectivity}

Connections between taste and subjectivity have deep roots in the Western psyche. These connections between taste and subjectivity were first established in eighteenth-century Europe, where a strong relationship between taste and the modern quest for identity were forged (Lindholm \& Lie, 2013). In short, our ideas regarding taste are coupled with modern bourgeois notions of subjectivity. As the bourgeoisie were trying to consolidate power in opposition to the aristocracy, they also were trying to redefine social mores and manners (Arendt, 1961; Elias, 1978).

Taste became an important aspect of eighteenth-century life. Philosophers like Hume and Kant spent much time and effort weighing the contradictions implicit within commonplace 
notions of taste. On the one hand, Hume took a sensory approach, connecting taste with feeling (Highmore, 2016). On the other, Kant had two opposing ways of conceiving taste. First, in the Critique of Judgement, originally entitled the Critique of Taste (Arendt, 1992), Kant (2005) argues that "everyone has their own taste," meaning there can be "no disputing for taste" (pp. 137/8). In effect, we each have our individual likes and dislikes that others may not agree with, but cannot readily dispute. In taste's second meaning, Kant connects taste with our capacity for judgement. Taste matters, he argued, because it enable us to judge, both from an aesthetic and from a moral perspective. Such a judgement can not only be communicated but also universally comprehended.

Individual taste consists, if we follow Kant, of the private sensations of the palate, tongue and throat, unique to each one of us. Yet taste is also connected with judgement, and is thus public or intersubjective in nature. Bourdieu contended Kant's view of taste and aesthetics ushered in a bourgeois sensibility that not only privileged disinterestedness, it also encouraged a negative bias against the taste preferences of the working class. This focus on disinterestedness is for Strati (1999) the reason why Kantian aesthetics, unlike phenomenological or hermeneutical approaches, "cannot act as a theoretical referent for the aesthetic understanding of organizations" (p. 110). But there is a theorist steeped in the phenomenological tradition who suggests Kantian aesthetics can be fruitful in thinking about taste - that is, Arendt, to whom I now turn.

\section{Taste and intersubjectivity}

Following Kant, Arendt argued taste is the sense most unique to each of us. If someone dislikes something, Arendt (1992) maintains that no argument can persuade someone to change their mind. Consequently, "there can be no dispute about matters of taste" (p. 75). Because of its indisputable aspect, she argues taste represents "the most intimate, private and idiosyncratic of 
the senses, the opposite of sight, with its noble distance" (p. 111). Not only is taste our most "silent sense," it also belongs to the realm of aesthetics (p. 215).

Yet, like Kant, Arendt seems to contradict herself when she declares that taste is also intersubjective. Thus, in taste's second form, it is not concerned with individual preference, but rather in making a claim to universality. This is done through the activity of judging, something we can all engage in, because we are members of the sensus communis. Rather than being the domain of the discerning few, taste is what we hold in common. Through taste we decide who belongs together because of shared common interests. Hence, judgments of taste are intersubjective, Arendt (1961) maintains, since individuals are always part of a particular community (p. 67).

Relating this to organizational life, one could argue that each organization possesses its own distinctive taste that relate to its cultural, social and historical circumstances. Tastes are affected by the convergence of "traditions, the celebration of human relationships and the valorization of local savoir-faire" (Croidieu et al., 2017,p. 1). Such traditional awareness of local cuisine influence ideas about taste, and has an effect on how particular organizations are perceived, as we saw in the example of the fish and chip shop.

Those involved in food preparation do not usually receive the kind of societal esteem shown to craft workers. Put simply, those who labour in occupations involved with life's necessities do not usually receive as much recognition as those who make things of lasting value. Arendt (1958) distinguishes between labour and work, arguing that workers who make objects that have lasting value usually have a higher social standing than those whose labour produces ephemeral things, such as food. This prejudice against those who work in what we now call the 
service sector is still apparent, even though there are famous chefs whose work receives societal accolades.

Arendt (2018) contends that "[t]aste commands an organizational power and peculiar strength" [that decides] "not only what the world would look like but also who belongs together" (p. 183). There is a place in Tuscany called Bargona that has an annual fish and chip festival each summer to celebrate its Scottish connections (Smith, 2014). In the nineteenth century, many families moved away from this beautiful Italian city to seek their fortunes in Scotland. Over time, Italian families owned $80 \%$ of the Scottish fish and chip trade. Today, an estimated 20,000 Scots are of Italian origin. Each year, many Scottish families travel to their ancestral home of Bargana, drinking in the beautiful countryside, celebrating their historical roots, and a collective sense of belonging.

Stories such as these offer insight into the history of organizations and how specific groups cherish their collective past. These historical narratives help us understand why particular groups are connected to specific businesses. But they tell us much more about organizational and societal notions of belonging. Thinking with Arendt can offer insight into the interconnections amongst particular stories and ways of working and living together. Such stories are fundamental to how narratives represent a form of organizing (Czarniawska, 2012), but also to a comprehension of the human condition more generally (Arendt, 1958). Arendt's work is also relevant to organizational aesthetics, because of her work on the connections between taste and judgement. That said, she does not provide insight into the affective, embodied, nature of taste. For that, we must turn to Antoine Hennion.

\section{A pragmatic approach to taste}


Unlike Arendt, Hennion (2015) argues that we can have disagreements when it comes to taste. Taste is a complex issue that, he contends, cannot be fully comprehended by surveying people's preferences. According to Hennion, there are methodological drawbacks to the kind of statistical sampling that some sociologists conduct. This is because people often tell researchers what they think they want to hear. But to understand taste, Hennion argues researchers need to spend less time asking questions and more time engaged in conversations with people.

By listening attentively, researchers can learn that it is not only organizations that shape people's tastes but also the objects and practices with which they form attachments. Hennion (2015) maintains that those who can shed the most light on the relational nature of taste are not experts in a particular field, but rather amateurs. In his view, an amateur is somewhat who is passionate about a particular activity. It is through listening to how an individual describes the activity or object they hold dear that we may obtain greater insights into taste.

Furthermore, Hennion contends that the sociology of culture has trained sociologists to critique people's taste preferences, to see them as cultural dupes. This is his quarrel with Bourdieu's approach to understanding taste. Unlike Bourdieu, Hennion (2016) maintains that people are aware of their tastes, and how they are shaped by circumstances. Here Hennion's argument complements that of Arendt, especially when he contends that taste represents "part of our common knowledge of the world" (p. 105). He further contends that taste encompasses our practices, as well as our attachments to things. Accordingly, taste is neither a property of a thing nor a person, rather it is an activity that connects taste with feeling (Hennion, 2015; Highmore, 2016b).

If we wish to grasp the subjective meaning of taste what is required is a deeper attention to subtle changes in experience. As an example, Hennion (2015) compares two guests at a dinner 
party sipping wine. The first guest continues to converse with others as he drinks his wine, whereas the second guest sips his wine, puckers his lips, and sniffs the wine's aroma. For just a moment, the second guest is fully engaged with the taste of wine. What this momentary attention represents is the "spontaneous management of a plurality of relations to one's body, to others, to things and events" (p. 38). Tasting evokes a heightened level of intensity, revealed by the heightened attention we pay to something. Consequently, for Hennion, "taste is always an attention" (p. 50).

For this attentiveness to come to the fore, what is needed is a letting-go of the desire for mastery over a situation. Hennion contrasts the amateur's attentiveness to the wine with that of professional wine tasters. In many professional tastings, he contends there is a focus on aspects extraneous to the tasting of wine, such as the conditions in which the wine was produced, or the terroir of a particular region. Furthermore, the expert tries to control the wine-tasting by having strict procedures for blind tests. Yet Hennion argues these experts confuse their expertise with the understanding of what wine tastes like in a particular situation. In their desire to control the situation, they fail to recognize how taste requires a willingness to forego mastery of the situation. Instead, one must allow the taste of wine to unfold in the moment. This unfolding is something that the amateur wine-taster knows since they are aware that tastes changes through our different "moods, penchants and habits" (p. 42). In short, things affects us, just as we affect them. Thus, our relationships are not just with people, but with the things that surround us.

For Hennion (2016), taste is not a property but rather an activity. This active component of taste influences how we relate to objects. Rather than viewing objects as symbols, we need to see how they "create their actors and organizations (p. 293). Objects have their own agency, influencing the way that we relate to the things around us. If we think back to Hockney's 
depiction of the fish and chip shop, what is noticeable is the simplicity of the objects he foregrounds. This simple arrangement of objects and people is a distillation of an organization at a particular moment in time. Just like the figures depicted in the print, the objects have their own place and work to form "a tissue of associations" (p. 293).

Tastes, pleasures and affects are not exogenous variables that can be plotted on a graph, but rather an intertwining of bodies, things and practices (Hennion, 2007). Far from being abstract determinations or passive inclinations, tastes represent an active component of our individual and collective, identity. From this perspective, taste is a corporeal practice that is not just socially constructed; neither is it purely aesthetic. Rather, taste involves an intermingling "of the body that tastes and the taste of the object, the group that loves it and the range of things they love" (p. 112).

Considering taste as practice enriches our understanding of the relational aspects of tasting. Thus Hennion's work opens up new ways of thinking about taste as feeling, cognizant of the embodied, affective, interplay between people and things, valuable for the study of organizations. When we see taste as an embodied, cultural practice (Ward, 2010), it opens up new ways of thinking about organizational practices, and productive lines of theoretical inquiry for organization studies (Gomez \& Bouty, 2011).

\section{Taste, organizations, and new directions}

In drawing together the disparate strands of this inquiry, what have we learned about taste, and its place within the field of organizational study? First, it is clear that taste is a multifaceted concept. This is why, as DiMaggio and Mohr (1985) maintain, we need to consider taste from different dimensions. In doing so, it is easier to "assess the full breadth of a person's taste" 
(Van Eijik, 2001, p. 1181). Such a full bodied assessment is enhanced by organizational research that draws on different perspectives and historical traditions (Savage, 2015).

Understanding taste is thus connected to our socio-historical and cultural milieu, and how diverse segments of the population eat and drink in particular ways that have cultural significance (Elias, 1978). But taste is also a practice that not only changes over time, but also serves to reproduce social class (Bourdieu, 1984; Highmore, 2016a). Not only are our eating habits being influenced by social class, they are also influenced by other markers of identity. To understand taste as it is felt and practiced in diverse bodies and places we need to recognize that class is not the only salient indicator. As Highmore (2015) informs us taste "modulates our experiences as gendered and raced bodies in the world" (p. 163). Consequently taste is not only about individual preferences, it is part of our ever-changing experiences, which change over time and place.

In addition to taste's temporal and special aspects, national identity has a bearing on organizational practices and cultural preferences (Cunha, et al., 2008; Savage, 2015). Even in relatively egalitarian societies, one's social and cultural background has a bearing on taste. In their study of Norwegian tastes, for example, Flemmen, Hjelibrekke \& Jarness (2018) reveal how culinary tastes are influenced by local culture and social class. In addition, Wright, Purhonen \& Heikkilä (2013) research findings indicate that Finnish people have a more emotional connection to their national dishes than British people do. As such, individual tastes are influenced differently by our shared practices in diverse national cultures and their diverse histories. These shared practices have an influence on our ideas about taste and organizations. Organizational practices also affect ideas about taste. This is especially the case when people gather together to celebrate organizational accomplishments, by sharing food and drink 
(Keevers \& Sykes, 2016). Yet organizations can actively encourage or discourage employee engagement through practices that employees deem to be tasteful, or distasteful (Plester, 2015). Accordingly, an organization's encouragement of particular practices can have a bearing, both positive and negative, on the affective relationships between an organization and its employees. Changing ideas about tastes are not only influenced by individual aspirations, but also by emergent social movements (van Bommel \& Spicer, 2011). Furthermore, social mobility is another important facet in understanding how individual tastes change (van Eijck, 2001). Attending to taste can illustrate how organizational practices shape subjective and collective preferences (Highmore, 2011).

Societal ideas about taste also shape the way we perceive organizations. Moreover, societal judgements about an organization's taste, or lack thereof, influence people's choice of workplace, as well as perceptions of what constitutes valuable work. Societal taste has an influence on which people chose to work in a specific setting, and what specific organization look like. Considering how taste influences particular sensibilities at work could enhance research in organizational studies. One line of inquiry could be to map how Bourdieu's notion of habitus has affinities with Hennion's discussion of attention. A complementary approach to these two thinkers offers potential for understanding how socio-historical attachments influence organizational tastes. Additionally, Bourdieu's work is still relevant to our understanding of the production and reproduction of societal inequities (Coulangeon \& Duval, 2015).

What is vital for organizational discussions about taste, then, is not to jettison Bourdieu's arguments about taste, but rather to investigate its relevance in different cultural, social, and temporal spaces (Coulangeon \& Duval, 2015). A focus on space, for instance, could lead to new research that connects taste with the organizational history of the small shop owner. Another 
approach might be to investigate how ephemeral organizations, such as pop up stores, shape our collective, and individual, tastes about what constitutes organizational life.

Arendt's work on taste as judgement could complement existing scholarship on organizational aesthetics. Adopting an Arendtian approach offers us a different lens through which to connect organizational taste with cultural judgements that emphasizes the importance of historical narrative of organizational life. Furthermore, she shows us how taste is an organizing principle, affecting ideas about work, as well as influencing notions of institutional belonging. An Arendtian analysis may also offer new directions for considering organizations and questions of value, relevant to the fledging discipline of Valuation Studies (Lamont, 2012).

Conversely, when we see taste as a practice, it offer insight into its affective dimensions, something Highmore (2016a) argued is fundamental to a deeper understanding of taste. Viewing taste as practice, as scholars like Gherardi (2009) and Hennion (2007, 2015) do, thus encourage scholars to engage in a "self-reflexive process of engaging with the sensorial world" (Highmore, 2016a, p. 163). Such a reflexive practice enables us to understand taste at a more sensory level, and alerts us to the different ways in which we value some organizations more than others.

What we value partially depends on what others in our scholarly discipline consider as valuable (Lamont, 2012). One problem with this value-laden way of seeing is that it may result in items being left off the disciplinary menu. I suggest this has been the case with Arendt. Yet engaging with her work has much to offer, enabling the kind of reflexive inquiry den Hond and Holt (2013) advocate for in their call for organizational scholars to heed Kant's maxim "Sapere Aude." Daring to know is not just about expanding our knowledge in the field of organizational inquiry, but also relates to our ideas about taste. As Nietzsche once observed, from an etymological perspective, the desire for wisdom was originally connected to the desire to taste 
(Agamben, 2017). For Arendt, that wisdom or practical knowledge can be enriched by thinking about taste from multiple perspectives.

Organizational scholarship is concerned with how organizations are arranged in particular ways (Hjorth \& Reay, 2018). When we think historically about the interconnections among taste and organizations, we add a richness to organizational research. Thinking about taste, therefore, helps scholars gain insight into organizational aesthetics, as well as broader societal preferences and organizational practices.

Organizational practices illustrate not just the production of taste preferences, but also the reproduction of social life (Gherardi, 2009). This inquiry has considered how a particular organization was constructed by particular socio-historical and cultural perceptions of taste, so as to explore taste from diverse perspectives. Understanding some of the complexities concerning taste is intrinsically connected to how we speak about the topic with others (Gallegos \& McHoul, 2006). In speaking about taste, I have attempted to convey how diverse perspectives offer new avenues of inquiry for organizational scholarship. By viewing taste through different vantage points, organizational scholars can obtain diverse insights into taste, and much theoretical food for thought.

\section{CODA}

As I complete this piece of writing, I come across a quote from Strati (1999) which states that "[e]veryone who belongs to an organization, even if temporarily, possesses aesthetic knowledge about it” (p. 112). I am suddenly reminded of something I had forgotten; my own labour in a fish and chip shop. As a young woman, I had many after school jobs. One short-lived employment was at a sit-down chippy called "The Fisherman's Catch." Perhaps I had forgotten 
about this experience because my career was so short-lived; maybe no longer than a month. In any event, my role was to clear the tables. It was not a pleasant job, although the place itself was lively. As I cleaned the tables, I thought wistfully of how great it must be to serve the customers. In speaking with another female employee, however, I learned that serving fish and chips had its downsides, since being close to the frying equipment meant that the oil smell got into your hair, and you could never wash the odour away. Perhaps it was this knowledge, or more likely boredom, that made me quit that job, and go to work for the greengrocer across the street. I cannot recall. What I do know is that taste memories, organizational or otherwise, have their own way of surfacing, and bringing ideas to the fore. Perhaps, then, we have arrived at the beginning of my interest in the fish and chip shop; an interest that stems from a long-forgotten memory of a working experience. Does this experience mean that I have greater insight into taste and organizations? I do not know, although I do have a greater appreciation for how habitus links us to our past in ways we are not always aware.

My sincere thanks to the three reviewers who helped me shape this essay in a more tasteful fashion. 


\section{References}

Agamben, G. (2017). Taste, trans. C. Francis. London, New York \& Calcutta: Seagull.

Arendt, H. (1958). The human condition. Chicago: Chicago University Press.

Arendt, H. (1961). The crisis in culture: Its social and its political significance. Between past and future (pp. 197-227). London and New York: Penguin.

Arendt, H. (1992). Lectures on Kant's political philosophy, ed. R. Beiner. Chicago: The University of Chicago Press.

Arendt, H. (2018). Culture and Politics. In Arendt, H., Thinking without Bannisters: Essays in Understanding, (pp. 160-80), ed. \& intro. J. Kohn, New York: Shocken Books.

Baskerville, J. (2017). 5 minutes with. . . An early Hockney print that hung in his local chip shop. https://www.christies.com/features/James-Baskerville-tells-the-story-behindDavid-Hockney-print-Fish-and-Chip-Shop-8149-1.aspx. Accessed April 29, 2017.

Brightman, C. (Ed.) (1995). Between friends: The correspondence of Hannah Arendt and Mary McCarthy, 1945-1975. London: Secker \& Warburg.

Bourdieu, P. \& Wacquant, L. (1992). An invitation to reflexive sociology. Chicago: Chicago University Press.

Bourdieu, P. (1984). Distinction: A social critique of the judgement of taste, transl. R. Nice. London: Routledge and Kegan Paul.

Brown, M. (Feb 14, 2017) Pride of Plaice: Hockney print that hung in Bradford chippy goes up for sale.

https://www. theguardian. com/artanddesign/2017/feb/14/david-hockney-print-fish-andchip-shop-bradford. Accessed April 29, 2017. 
Coulangeon, P. \& Duval, J. (Eds.) (2015). Introduction. The Routledge Companion to Distinction. London \& New York: Routledge.

Coulangeon, P. (2014). Social mobility and musical tastes: A reappraisal of the social meaning taste eclecticism. Poetics, 51, 54-68.

Croidieu, den Hond, F., Moser, C., Reinecke, J. \& Svejenova, S. (2017). Call for papers, Food Organizing Matters: Paradoxes, Problems and Potentialities, Organization Studies, 1-2.

Cunha, Pino, M., Cabral-Cardosa, M. \& Clegg, S. (2008). Manna from heaven: The exuberance of food as a topic for research in management and organization. Human Relations, 61, 7, 935-963.

Czarniawska, B. (2012). Narrating organization studies. Narrative Inquiry, 21, 2, 337-344.

DiMaggio, P. \& Mohr, J. (1985). Cultural capital, educational attainment, and marital selection. American Journal of Sociology, 90, 6, 1231-1258.

Elias, N. (1978). The history of manners. The civilizing process: volume 1, transl. E. Jephcott. New York: Pantheon Books.

The National Fish Fryers Federation. Available at: www.federationoffishfriers. co. uk. Gagliardi, P. (2007). The collective repression of 'pathos' in Organization Studies, Organization, $14,3,331-338$.

Gherardi, S. (2009). Practice? It's a matter of taste! Management Learning, 40(5): 535-550.

Gomez, M. L, \& Bouty, I. (2011). The emergence of an influential practice: Food for thought. Organization Studies, 32, 7, 921-940.

Hennion, A. (2007). Those things that hold us together: Taste and Sociology. Cultural Sociology, $1,1,97-114$. 
Hennion, A. (2015). Paying attention: What is tasting wine about? In Berthoin Antal, A., Hutter, M., \& Stark, D., (Eds.), Moments of valuation: Exploring sites of dissonance (pp. 35-55). Oxford. Oxford University Press.

Hennion, A. (2016). From ANT to Pragmatism: A journey with Bruno Latour at the CSI. New Literary History, 47: 289-308.

Highmore, B. (2016a). Taste after Bourdieu. New Formations, 159-163.

Highmore, B. (2016b). Taste as feeling. New Literary History, 47, 547-566.

Hjorth, D. and Reay, T., 2018. Organization Studies: moving entrepreneurially ahead. Organization Studies, 39, 1, 7-18.

Holt, R., \& den Hond, F. (2013). Sapere Aude. Organization Studies, 34, 11, 1587-1600.

Kant, I. (1790/2005). Critique of judgement, trans1. J. H. Bernard. New York: Dover Publications, Inc.

Keevers, L. \& Sykes, C. (2016). Food and music matters: Affective relations and practices in social justice organizations. Human relations, 69, 8, 1643-1668.

Lamont, M. (2012). Toward a comparative sociology of valuation and evaluation. The Annual Review of Sociology, 38, 21, 1-21.

Lindholm, C., \& Lie, S. B. (2013). You eat what you are: Cultivated taste and the pursuit of authenticity in the Slow Food Movement. In Osbaldiston, N., (Ed.) Culture of the slow: Social deceleration in an accelerated world. London and New York: Palgrave MacMillan.

Lizardo, O. (2014). Taste and the logic of practice in Distinction. Sociologicky casopis/Czech Sociological Review, 50, 3, 336-364.

Panayi, P. (2014). Fish and chips: A social history. London: Reaktion Books. 
Perullo, N. (2015). Taste as experience: The philosophy and aesthetics of food. Foreword by M. Montanari. New York: Columbia University Press.

Peterson, R. A., \& Kern, R. M. (Oct. 1996). Changing highbrow taste from snob to omnivore. American Sociological Review 61, 5, 900-907.

Plester, B. (2013). Ingesting the organization: The embodiment of organizational food rituals. Culture and Organization, 21, 3, 251-268.

Smith, K. (Mar 3, 2014). Italians settled in Scotland and loved the plaice. http://www. heraldscotland. com/opinion/13148642. Italians_settled_in_Scotland_and_loved_the_plaice/. Accessed April, 29, 2017.

Strati, A. (1990). Aesthetic understanding of organizational life. Academy of Management Review, 17, 3, 568-581.

Strati, A. (1999). Organization and aesthetics. London and Thousand Oaks, CA: Sage.

Strati, A. (2010). Aesthetic understanding of work and organizational life: Approaches and research developments. Sociology Compass 4/10: 880-893.

Van Bommel, K. \& Spicer, A. (2011). Hail the snail: Hegemonic struggles in the slow food movement. Organization Studies, 32, 12, 1717-1744.

Van Eijck, K. (2001). Social differentiation in musical taste patterns. Social Forces, 79, 3, 11631184.

Walton, J. K. (1994). Fish \& chips and the British working class, 1870-1940. London: Bloomsbury.

Ward, A. (2010). Cultural hostility re-considered. Cultural Sociology, 5, 3, 341-366.

Willis, P. (2018). Cultural production in perpetuity. Ethnography, 19, 4, 577-587. 
Wright, D., Purhonen, S., \& Heikkilä, R. (2013). Comparing “Cosmopolitanism:” Taste, nation and global culture in Finland and the UK, Comparative Sociology, 12, 330-360. 